\title{
Pendampingan Pembuatan Kompor Energi Alternatif Berbahan Bakar Limbah Serbuk Kayu dan Sekam Padi di Kelurahan TPU Keramat Cereme Taba Lubuklinggau
}

\author{
Yaspin Yolanda ${ }^{1}$, Ahmad Amin ${ }^{2} \&$ Armi Yuneti ${ }^{3}$ \\ ${ }^{123}$ STKIP PGRI Lubuklinggau
}

DOI: https://doi.org/10.29303/jpmpi.v4i2.814

Sitasi: Yolanda. Y., Amin, A., \& Yuneti, A. (2021). Pendampingan Pembuatan Kompor Energi Alternatif Berbahan Bakar Limbah Serbuk Kayu dan Sekam Padi di Kelurahan TPU Keramat Cereme Taba Lubuklinggau. Jurnal Pengabdian Magister Pendidikan IPA, 4(2)

\section{Article history}

Received: 30 April 2021

Revised: 23 Mei 2021

Accepted: 01 Juli 2021

*Corresponding Author: Yaspin Yolanda, STKIP PGRI Lubuklinggau, Indonesia; JL. Krakatau number 31 RT.7 Kelurahan Jawa Kiri 1 Lubuklinggau City, South Sumatra Province Email: yaspinyolanda@ymail.com

\begin{abstract}
Based on the observations we made in the TPU Keramat Cereme Taba Village, which is part of the area in Lubuklinggau City, most of the people make a living as wood craftsmen and farmers often cause problems, namely the increasing number of piles of sawdust and rice husks that have not been handled, then the high gas elpigi because it is difficult to find and the community. The goal is to manufacture energy-efficient stoves fueled by sawdust and rice husk waste as a solution to overcome waste. The method of implementing the activities is in the form of lectures, demonstrations and direct practicums. The implementation time is March to June 2021. The target of this activity is youth and women in the village. Evaluation of the increase in participants' knowledge was carried out by pre- and post-test after socialization. The evaluation of participants' skills was carried out during a direct demonstration of stove making. The results of the PKM implementation showed success because there was an increase in knowledge of around 87.5 percent, namely (a) an increase in participants' knowledge about the usefulness of sawdust and rice husk waste by 89 percent. (b) Increased knowledge during media demonstrations about the efficiency of sawdust and rice husk stoves (KOKADI) compared to Elpigi Gas Stoves by 87 percent. (c) Increased knowledge of KOKADI stove maintenance techniques by 88 percent. And (d) Improving community skills regarding the manufacture of KOKADI stoves by 86 percent. This service activity is classified as successful, with an average increase of more than 70 percent, which is an increase of around 87.5 percent. All participants attended PKM activities starting from the opening, the benefits of sawdust and rice husk waste, simulating the manufacture of KOKADI stoves, and observing directly the process of comparing the efficiency of KOKADI with Elpigi gas stoves (KGE).
\end{abstract}

Keywords: Waste, Alternative Energy Stove, Wood Dust, Rice Husk

\section{Pendahuluan}

$\mathrm{K}_{\mathrm{b}}$ elurahan TPU Keramat Cereme Taba adalah bagian wilayah di Kota Lubuklinggau. Potensi wilayah yang kaya akan sumber daya alam yang sangat berlimpah yakni sumber daya alam berupa hutan. Seiring dengan meningkatnya jumlah penduduk di Indonesia dan semakin majunya teknologi, kebutuhan kayu hutan olahan sebagai bahan bangunan semakin meningkat setiap tahun. Soedomo (2001) mengemukakan bahwa kebutuhan kayu untuk industri perkayuan di Indonesia diperkirakan sebesar 70 juta $\mathrm{m}^{3}$ per tahun dengan kenaikan rata-rata sebesar $14,2 \%$ pertahun, sedangkan produksi kayu bulat diperkirakan hanya 
25 juta $\mathrm{m}^{3}$ per tahun. Wijoyo (2017) menyebutkan bahwa Data Forest Watch Indonesia (2001), menunjukkan bahwa laju pengurangan hutan di Indonesia 1,821,913 ton dengan kebutuhan kayu yang terus meningkat tersebut dan potensi hutan yang terus berkurang menuntut penggunaan kayu yang menghasilkan limbah serbuk kayu semakin meningkat, karena belum terkelolahnya dengan baik dalam mengatasi limbah serbuk kayu.

Serbuk gergaji merupakan limbah dari hasil kegiatan pengolahan kayu. Biasanya serbuk gergaji dapat dihasilkan setelah melakukan proses penggergajian kayu ataupun proses penghalusan dari kayu dengan menggunakan alat penghalus kayu. Syafii (2006) menyatakan bahwa kandungan serbuk kayu terdiri dari selulosa, helmiselulosa, lignin dan ekstratif. Soekandi, dkk (2013) menyatakan bahwa kayu memiliki struktur kimia tersusun atas selulosa, lignin dan hemiselulosa. Selulosa sebagai kerangka, hemiselulosa sebagai matrik, dan lignin sebagai bahan pengikat sel-sel dan memberikan kekakuan kepada dinding sel. Selulosa adalah komponen utama dinding sel. Molekul selulosa dibentuk oleh \pm 10.000 monomer glukosa yang diikat dengan ikatan 1,4- $\beta$-glukosida. Setiap monomer glukosa memiliki tiga gugus hidroksil (-OH). Asfar, dkk (2019) mentakan bahwa sebanyak 36 molekul selulosa terikat bersama-sama oleh ikatan hidrogen membentuk seberkas fibril elementer. Fibril elementer bergabung membentuk mikrofibril, kemudian mikrofibril bergabung membentuk fibril dan akhirnya membentuk serat-serat selulosa.

Soekandi, dkk (2014) menyatakan bahwa sekam padi memiliki struktur kimia tersusun atas selulosa, lignin dan hemiselulosa. Selulosa sebagai kerangka, hemiselulosa sebagai matrik, dan lignin sebagai bahan pengikat sel-sel dan memberikan kekakuan kepada dinding sel. Ditinjau data komposisi kimiawi, sekam mengandung beberapa unsur kimia penting seperti dapat dilihat di bawah. Komposisi kimia sekam padi yakni Kadar air $(9,02 \%)$, Protein kasar $(3,03 \%)$, Lemak $(1,18 \%)$, Serat kasar $(35,68 \%)$, Abu $(17,17 \%)$ dan Karbohidrat dasar $(33,71 \%)$. Sedangkan komposisi kimia sekam padi menurut DTC-IPB adalah Karbon/zat arang (1,33\%), Hidrogen (1,54\%), Oksigen $(33,64 \%)$ dan Silika $(16,98 \%)$.

Berdasarkan hasil observasi yang kami lakukan di kelurahan TPU Keramat Cereme Taba belum adanya penanganan terhadap limbah serbuk kayu dan sekam padi. Sumber permasalahan limbah serbuk kayu dan sekam padi di Kelurahan TPU Keramat Cereme Taba Kota Lubuklinggau adalah sebagian besar masyarakat bermata pencaharian sebagai pengrajin kayu dan petani.

Selama pandemi ini berlangsung, sebagian masyarakat masih mengandalkan kayu bakar untuk kebutuhan memasaknya, mahalnya gas elpigi $3 \mathrm{Kg}$ mencapai Rp. 30.000,- di masyarakat sebagai penyebab mereka memilih kayu bakar. Berdasarkan hasil analisa diatas, maka permasalahan yang kami simpulkan adalah pengelolaan limbah serbuk kayu dan sekam padi belum tepat guna karena belum adanya pengetahuan masyarakat mengenai pengelolaan limbah serbuk kayu dan sekam padi.

Pengelolaan limbah serbuk kayu dan sekam padi yang kita ketahui banyak diolah menjadi kerajinan tangan, media tanaman. Akan tetapi melihat potensi limbah serbuk kayu dan sekam padi yang menumpuk tanpa pengolahan, kami bermaksud akan mengolah limbah serbuk kayu dan sekam padi menjadi bahan bakar alternatif sebagai media bahan bakar dalam pembuatan kompor energi alternatif sehingga menjadi solusi terhadap permasalahan kelangkaan gas elpigi di kelurahan TPU Keramat Cereme Taba.

Berdasarkan uraian diatas, permasalahan utamanya adalah belum adanya pengetahuan masyarakat mengenai pengelolaan limbah serbuk kayu dan sekam padi, kelangkaan gas elpigi dan Kurangnya keterampilan masyarakat dalam mengelola limbah serbuk kayu menjadi produk teknologi. Karno (2013), Pujiati (2015) dan USAID (2015) menjelaskan pengelolaan limbah ini merupakan kegiatan yang sangat bermanfaat dan tentunya dapat meningkatkan pengetahuan dan keterampilan masyarakat dalam mengatasi limbah dengan proses daur ulang. Herlambang (2015) dan Indahyani, T (2010) menjelaskan pelatihan untuk meningkatkan keterampilan masyarakat sangat penting dilakukan dalam rangka meningkatkan kemandirian masyarakat dalam ekonomi. Vinda (2017) dan Setyaningrum, A (2020) menjelaskan bahwa pemberdayaan masyarakat merupakan salah satu upaya dalam mengatasi kesenjangan sosial di masyarakat yang bersifat people centered dengan pendekatan partisipatif agar memudahkan dalam mentransfer ilmu pengetahuan (Suryolaksono, 2015). 
Maka solusi untuk mengatasi permasalahan diatas adalah membuat kegiatan yang efektif. Lando, dkk (2019) dan Rud Rudiman, M., dkk. (2021) menyatakan bahwa kegiatan pengabdian akan efektif bila melibatkan perangkat desa setempat dan masyarakat untuk berpatisipasi bersama dalam mengatasi permasalahan limbah serbuk kayu dan sekam padi yakni berupa pengenalan dan pendampingan masyarakat tentang Kompor serbuk kayu dan sekam padi sebagai solusi dalam mengatasi limbah serbuk kayu dan sekam padi.

Adapun tujuan kegiatan ini (1) Mensosialisasikan tentang kebermanfaatan serbuk kayu dan sekam padi sebagai bahan bakar alternatif pada kompor serbuk kayu berbasis teknologi masyarakat. (2) Memberikan pengetahuan masyarakat untuk membandingkan efisiensi kompor serbuk kayu dan sekam padi dibandingkan dengan kompor gas elpigi. Dan (3) Mendampingi masyarakat dalam keterampilan membuat kompor serbuk kayu dan sekam padi dengan menggunakan barang bekas.

\section{Metode}

Tempat dan Waktu. Kegiatan PKM dilaksanakan di Kelurahan TPU Keramat Cereme Taba Kecamatan Lubuklinggau Timur 1 Kota Lubuklinggau selama 3 bulan mulai dari bulan Maret s.d. Juni 2021. Tempat kegiatan PKM ditempuh selama 30 Menit dari STKIP PGRI Lubuklinggau.

Khalayak Sasaran. Kegiatan PKM dihadiri remaja dan ibu-ibu kelurahan TPU Keramat Cereme Taba Kecamatan Lubuklinggau Timur 1 Kota Lubuklinggau. Jumlah peserta yang mengikuti kegiatan dari awal hingga akhir adalah 16 orang ibu-ibu.

Metode yang digunakan untuk melaksanakan Pengabdian. Adapun metodenya adalah (1) ceramah dan diskusi dan (2) Demonstrasi praktik langsung pembuatan kompor berbahan bakar serbuk kayu dan sekam padi menggunakan barang-barang bekas, serta bimbingan dan pendampingan teknis pembuatan dari Dosen dan Mahasiswa. Ceramah dan demonstrasi secara langsung dilakukan bersamaan dengan pertemuan rutin remaja dan ibu-ibu di rumah warga. Bimbingan dan pendampingan teknis dilakukan selama tiga bulan.
Indikator Keberhasilan Setiap Kegiatan Kegiatan PKM berhasil jika adanya peningkatan pengetahuan dan keterampilan kelompok masyarakat tentang 1) Kebermanfaatan limbah serbuk kayu mencapai $\geq 70 \%$, 2) Teknik pembuatan Kompor serbuk kayu dan sekam padi menggunakan barang bekas dan bahan bakar serbuk kayu dan sekam padi mencapai $\geq 70 \%$, 3) efisiensi Kompor serbuk kayu dan sekam padi dibandingkan dengan Kompor Gas Elpigi mencapai $\geq 70 \%$, dan 4) Teknik perawatan kompor serbuk kayu dan sekam padi mencapai $\geq 70 \%$.

Evaluasi keterampilan dilakukan pada saat demonstrasi praktik langsung. Peserta diminta memperhatikan dan menirukan proses pembuatan kompor serbuk kayu dan sekam padi dari barang bekas. Peserta yang mampu melakukan pembuatan kompor dianggap mampu melakukan keterampilan pembuatan kompor serbuk kayu dan sekam padi dengan benar.

Metode Evaluasi. Evaluasi tingkat penerimaan masyarakat terhadap pengetahuan dan kegiatan yang dilakukan diukur melalui angket dan wawancara sebelum dan sesudah kegiatan penyuluhan, diskusi, dan demonstrasi praktik langsung. Masyarakat diminta untuk mengerjakan angket dan menjawab pertanyaan wawancara yang kami ajukan secara mandiri. Rekapitulasi hasil angket yang diberikan dapat dilihat pada Tabel 1 dan 2 .

\section{Hasil dan Pembahasan}

\section{A. Persiapan}

Tahap persiapan dilakukan dengan menyiapkan alat dan bahan pembuatan kompor serbuk kayu dan sekam padi. Selanjutnya mempersiapkan angket yang akan digunakan pada tahap persiapan. Selain itu, penyiapan materi juga dilakukan pada tahap ini.

\section{B. Pelaksanaan}

Pembuatan teknologi kompor serbuk kayu dan sekam padi yang dilakukan pada kegiatan ini dimulai dengan ceramah dan diskusi. Ceramah dan diskusi dimaksudkan untuk memberikan pengetahuan mengenai 1) Kebermanfaatan limbah serbuk kayu dan sekam padi, 2) efisiensi Kompor serbuk kayu dan sekam padi dibandingkan dengan Kompor Gas Elpigi, dan 3) Teknik perawatan kompor serbuk kayu dan sekam padi. 4) Demonstrasi Media. Kegiatan penyuluhan 
disampaikan melalui presentasi dan secara visual menggunakan power point. Metode pendekatan tersebut ditempuh untuk memudahkan adanya transfer ilmu pengetahuan.

Setyabudhi (2017) mengatakan untuk melihat sebuah efisiensi kompor perlu dilakukan perbandingan dengan kompor energi yang lain. Maka pada saat penyuluhan dilakukan pembandingan efisiensi serbuk kayu dan sekam padi (KOKADI) dengan Kompor Gas Elpigi (KGE). Kami memberikan kesempatan diskusi untuk memenuhi kebutuhan informasi masyarakat tentang alat dan bahan yag digunakan dalam proses pembuataya serta kendala dan hambatan yang mungkin timbul saat proses pembuatan. Masyarakat sangat antusias dalam mengajukan beberapa pertanyaan terkait efisiensi Kompor serbuk kayu dan sekam padi dan Teknis perawatannya.

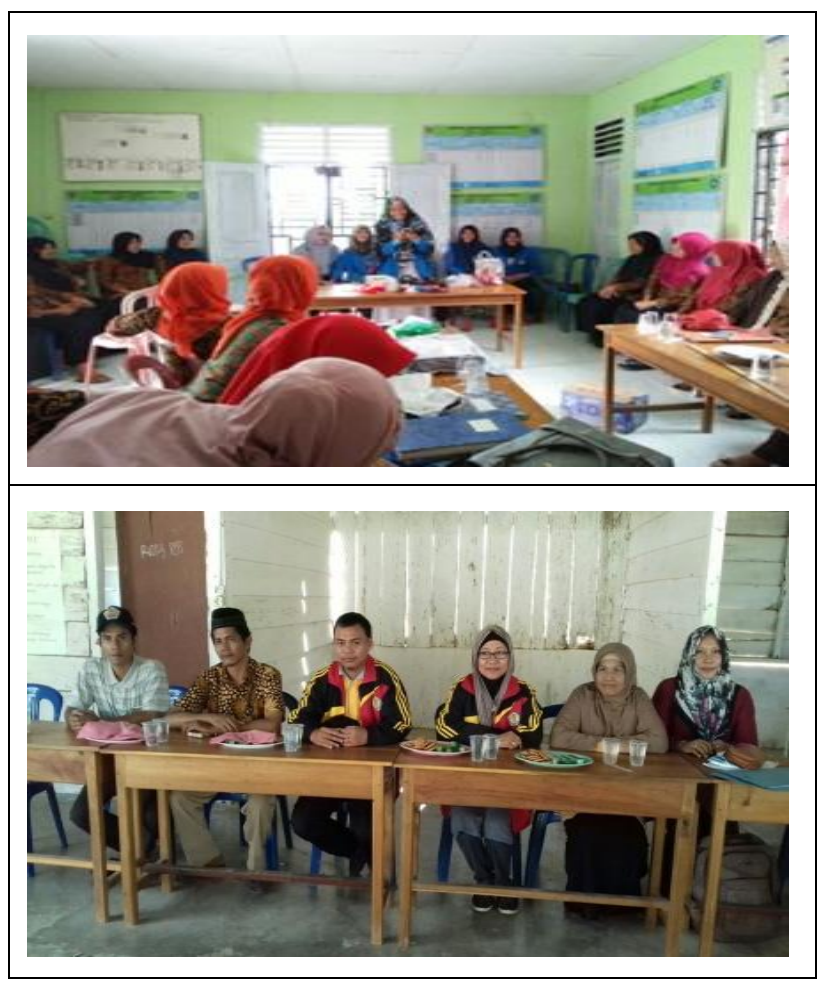

Gambar 1. Antusias Masyarakat dalam mengikuti pelatihan

\section{Demonstrasi Pembuatan Kompor}

Kegiatan selanjutnya adalah demonstrasi praktik langsung tentang pembuatan Kompor serbuk kayu dan sekam padi menggunakan barang bekas dan bahan bakar serbuk kayu dan sekam padi, serta demonstrasi langsung pembuatan kompor dan masyarakat langsung mempraktikkan pembuatan kompor dengan bimbingan tim. Effendi (2008) mengatakan bahwa masyarakat perlu diminta untuk mencoba mempraktekkan pembuatan kompor hemat energi agar pengetahuan lebih cepat didapat, hal ini senada dengan pendapat Sumarsono (2009). Adapun prosedur pembuatan kompor serbuk kayu dan sekam padi sebagai kompor hemat energi dari limbah serbuk kayu dan sekam padi sebagai solusi cerdas mengatasi limbah dengan menggunakan teknologi kerakyatan adalah:

a. Menyiapkan alat dan bahan. Adapun alat yang digunakan dalam pembuatan "Kompor serbuk kayu dan sekam padi" adalah mistar baja mengukur diameter lingkaran, Cutter untuk memotong, Pisau untuk melubangi kaleng, Kaleng Lem Bekas sebagai media utama kompornya, kuas yang digunakan untuk mengecat kompor, piva PVC yang berfungsi membuat corong, kaleng susu sebagai cerobong keluarnya api dan besi diameter $5 \mathrm{~mm}$ sebagai media utama tungku kompor. Adapun bahan yang digunakan adalah serbuk kayu dan sekam padi sebagai bahan bakar utama, minyak lampu sebagai penyulut api, cat warna memberikan warna pada kompor.

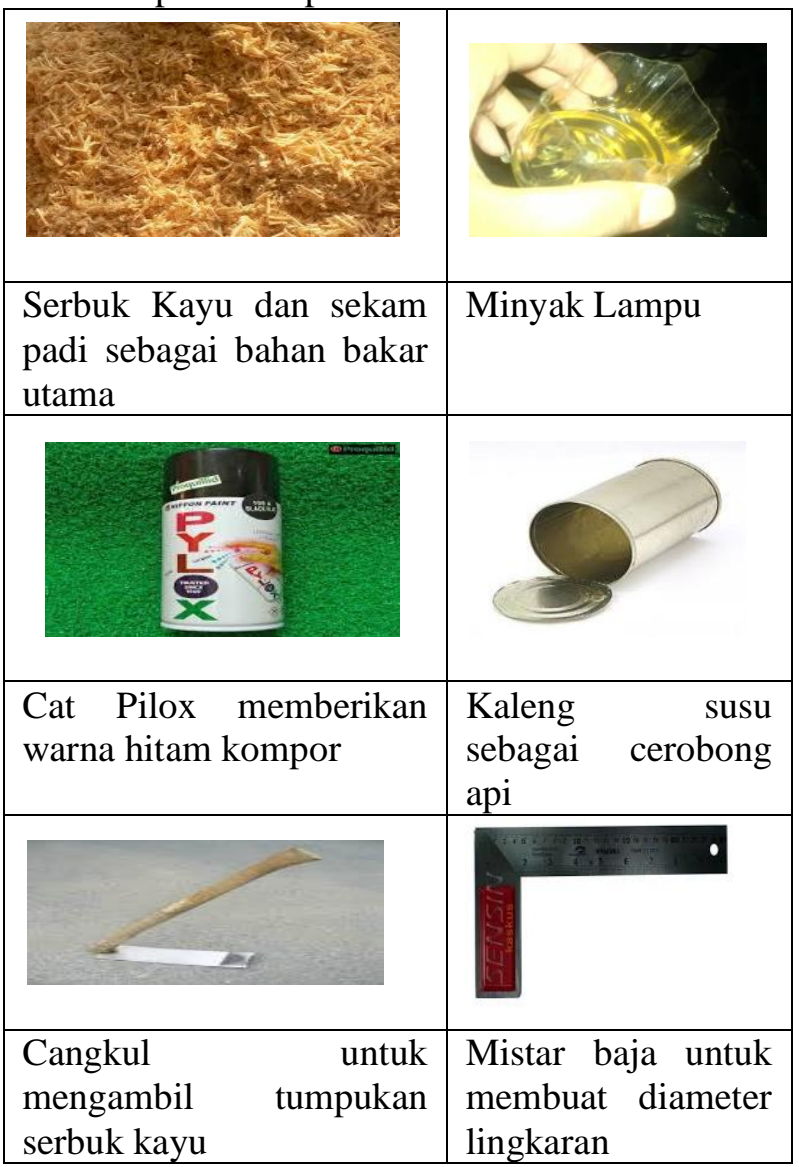




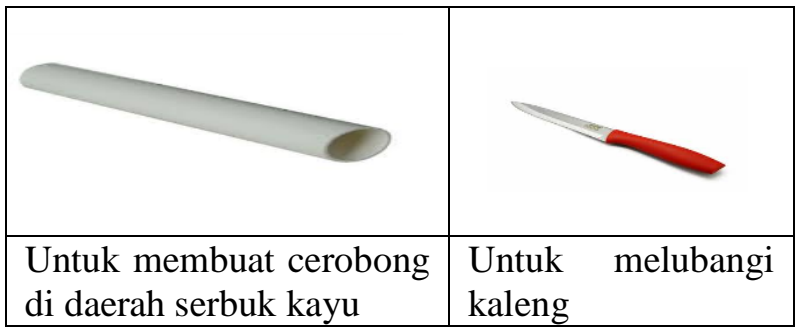

Gambar 2. Alat dan bahan pembuatan kompor

b. Prosedur Pembuatan kompor, setelah kita menyiapkan alat dan bahan diatas, selanjutnya kita akan melakukan proses pembuatan kompor, yakni ambil kaleng bekas lem fox sebagai media utama pembuatan kompor, dari bagian alas buat kotak bujur sangkar dengan dimensi sisi $10 \mathrm{~cm} \times 10 \mathrm{~cm}$. buat lubang sebagai tempat penyalaan api kompor dan lakukan pengecatan kaleng sesuai dengan warna yang kita inginkan dan dijemur pada terik matahari. Serta buatlah cerobong api dari kaleng kecil dan belah setengah badan kaleng kecil untuk memasukkan penutup dan pengaturan api.

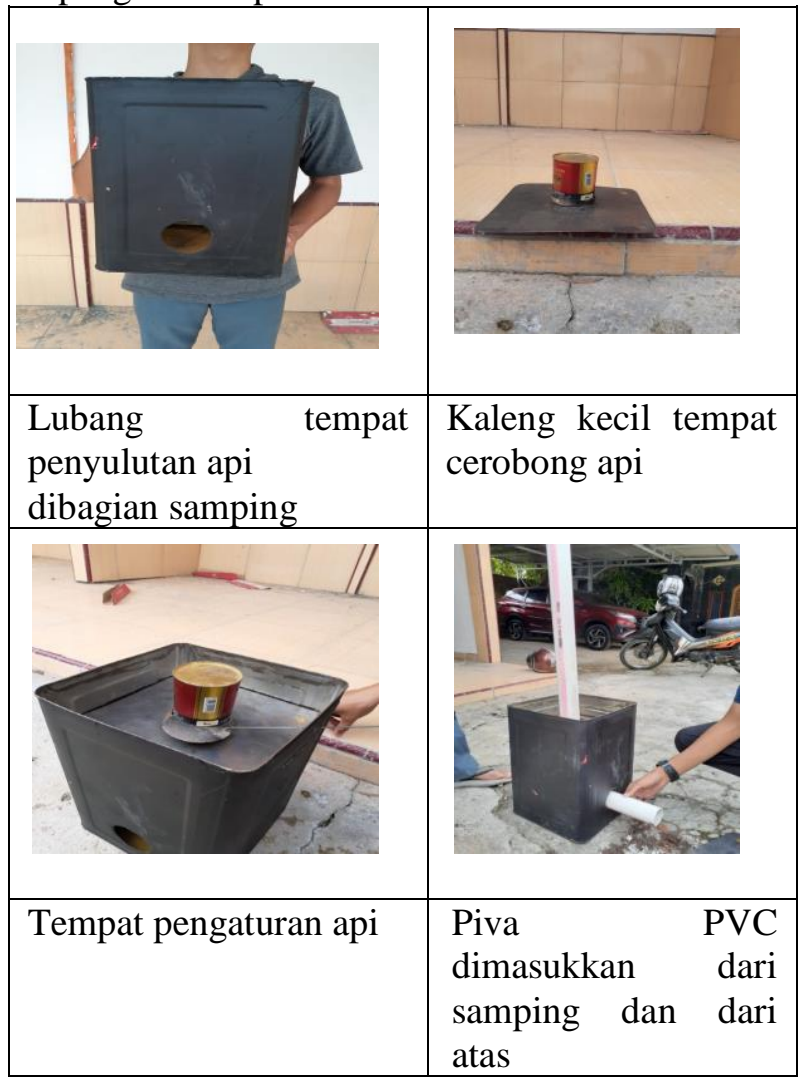

Gambar 3 Bentuk awal pada kompor c. Gambar 3. Ambillah besi kompong buatlah desain berupa segi empat dudukan tungku sesuai dengan ukuran wajan atau panci peralatan memasak yang kita inginkan.

d. Masukkan piva PVC tepat dibagian tengah kaleng hingga menyentuh bagian dasar kaleng. Dan dudukan kaki dimasukkan kedalam kaleng seperti gambar 3. Selanjutnya

e. Masukkan tumpukkan serbuk kayu dan sekam padi kering kedalam kaleng dan disekitar pipa dan lakukan proses pemadatan serbuk kayu dan sekam padi. Selanjutnya tarik pipa PVC dan akan terlihat tabung dibagian tengah serbuk kayu dan sekam padi yang telah dipadatkan.

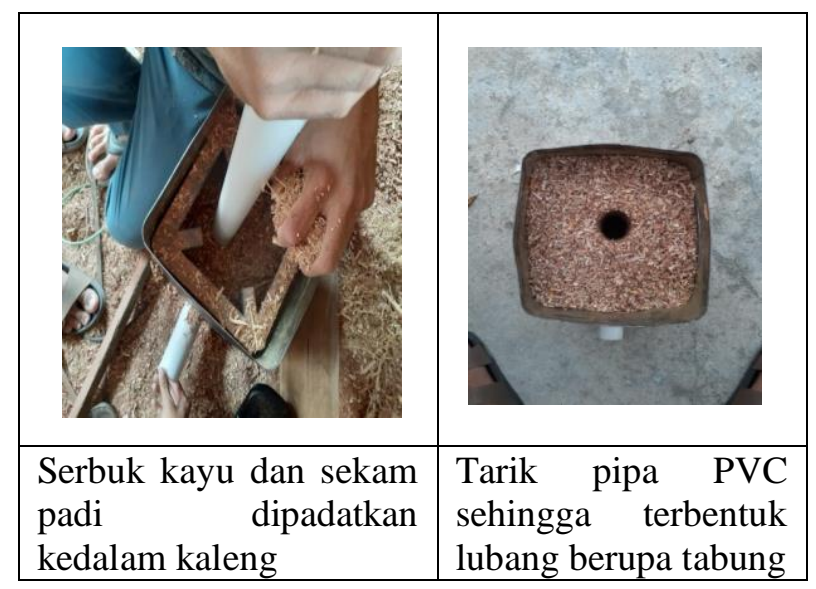

Gambar 4. Serbuk kayu yang telah dipadatkan kedalam kompor

f. Lakukan penyalaan api dibagian alas yang telah diberi lubang menggunakan sedikit minyak lampu.

\section{B. Keberhasilan Kegiatan.}

Sumarsono (2009) menyatakan bahwa proses mencari efisiensi perlu dilakukan dengan membuat variabel yang sama sehingga dapat diterima hasilnya. Maka kami melakukan proses mendemonstasikan media kompor serbuk kayu dan sekam padi (KOKADI) dan Kompor Gas Elpigi (KGE) dengan memasak 1 liter air hingga mendidih, kami menyebarkan kuisioner untuk mengukur efisiensi kompor serbuk kayu yang diberikan kepada 12 Responden yakni masyarakat yang berprofesi sebagai Pedagang Bakso, Nasi Uduk dan ibu rumah tangga. Kusisoner ini berupa pertanyaan yang diberikan tim penulis kepada responden yang sudah biasa menggunakan gas elpiji sebagai kompor dalam kebutuhan memasak 
sehari-hari. Selanjutnya kami meminta kesediaan responden untuk mengisi kuisioner pada tabel 3 . Sehingga didapat hasilnya menunjukkan Kompor serbuk kayu dan sekam padi (KOKADI) dalam efektivitas suhu dan waktu pemakaian, lebih hemat biaya, bahan bakar mudah dijumpai dan lebih praktis. Sehingga pendapat Effendi (2008) mengatakan bahwa efisiensi kompor hemat energi dilihat dari efisiensi suhu dan waktu pemakaian benar adanya.

Kebermanfaatan kegiatan PPM dan tingkat penerimaan masyarakat terhadap pengetahuan dan teknik yang diberikan dapat dievaluasi menggunakan metode pre test dan post test. Metode ini juga dilakukan oleh Dewi, P.S., \& Widiyawati, I. (2019) yang mengemukakan bahwa penerapan teknologi budidaya tanaman obat sebagai upaya pemanfaatan lahan pekarangan di Kelurahan Pabuwaran, Purwokerto, Jawa Tengah menunjukkan hasil yang baik ditinjau dari hasil perbandingan pre-test dan post-test. Agustinus, dkk (2014) dan Lando, dkk (2019) menyatakan bahwa keberhasilan kegiatan pengabdian terlihat adanya peningkatan pengetahuan mayarakat. Kegiatan pengabdian ini dikatakan berhasil dan bermanfaat jika:

1. Peningkatan pengetahuan kebermanfaatan limbah serbuk kayu dan sekam padi sebesar 70 persen.

2. Peningkatan pengetahuan saat demonstrasi media tentang efisiensi Kompor serbuk kayu dan sekam padi dibandingkan dengan Kompor Gas Elpigi sebesar 70 persen.

3. Peningkatan pengetahuan teknik perawatan kompor serbuk kayu dan sekam padi sebesar 70 persen.

4. Peningkatan pengetahuan dan keterampilan masyaraakat tentang pembuatan kompor serbuk kayu serbuk kayu dan sekam padi sebesar 70 persen.

Tabel 1. Rekapitulasi Jawaban responden

\begin{tabular}{|l|l|}
\hline \multicolumn{1}{|c|}{ Pertanyaan } & \multicolumn{1}{c|}{$\begin{array}{c}\text { Persentase Pilihan } \\
\text { Responden }\end{array}$} \\
\hline Efisiensi Waktu dan Suhu Pemakaian \\
\hline $\begin{array}{l}\text { Untuk memasak air } \\
\text { hingga mendidih, KGE }\end{array}$ & $\begin{array}{l}58 \% \text { tidak setuju } \\
25 \% \text { ragu-ragu } \\
\text { lebih cepat mendidih dari } \\
\text { pada menggunakan } \\
\text { kompor KBA. }\end{array}$ \\
\hline KBA memiliki penyalaan & $83 \%$ sangat setuju \\
\hline
\end{tabular}

\begin{tabular}{|c|c|}
\hline $\begin{array}{l}\text { api lebih lama dan stabil } \\
\text { dari pada KGE }\end{array}$ & $17 \%$ setuju \\
\hline $\begin{array}{l}\text { KGE lebih cepat panas } \\
\text { dari pada KBA }\end{array}$ & $\begin{array}{l}50 \% \text { tidak setuju } \\
17 \% \text { ragu-ragu } \\
33 \% \text { sangat setuju }\end{array}$ \\
\hline \multicolumn{2}{|l|}{ Kelangkaan bahan Bakar } \\
\hline $\begin{array}{l}\text { Menurut saya, KBA lebih } \\
\text { langka dan sulit } \\
\text { ditemukan dari KGE }\end{array}$ & $100 \%$ tidak setuju \\
\hline $\begin{array}{llr}\text { Serbuk } & \text { Kayu } & \text { mudah } \\
\text { dijumpai } & \text { sebagai } & \text { bahan } \\
\text { bakar KBA } & & \\
\end{array}$ & $100 \%$ sangat setuju \\
\hline \multicolumn{2}{|l|}{ Penghematan Biaya } \\
\hline $\begin{array}{l}\text { Menurut Saya, KGE lebih } \\
\text { hemat biaya dari pada } \\
\text { KBA }\end{array}$ & $100 \%$ tidak setuju \\
\hline $\begin{array}{l}\text { Menurut saya, KBA lebih } \\
\text { irit biaya dar pada KGE }\end{array}$ & $\begin{array}{l}83 \% \text { sangat setuju } \\
17 \% \text { setuju }\end{array}$ \\
\hline \multicolumn{2}{|l|}{ Kepraktisan } \\
\hline $\begin{array}{l}\text { Menurut saya, KBA lebih } \\
\text { praktis dalam pemakaian } \\
\text { kegiatan memasak diluar } \\
\text { misalnya perkemahan, } \\
\text { persedekahan }\end{array}$ & $100 \%$ sangat setuju \\
\hline $\begin{array}{l}\text { Menurut saya } \\
\text { memasak dengan jumlah } \\
\text { yang besar } \\
\text { memerlukan waktu masak } \\
\text { yang lama, KGE lebih } \\
\text { bisa diunggulkan }\end{array}$ & $\begin{array}{l}\text { 17\% sangat setuju } \\
33 \% \text { setuju } \\
50 \% \text { tidak setuju }\end{array}$ \\
\hline $\begin{array}{l}\text { Menurut saya, KBA lebih } \\
\text { praktis karena kompornya } \\
\text { bisa didalam tanah untuk } \\
\text { memasak dengan jumlah } \\
\text { yang besar di acara } \\
\text { persedekahan misalnya } \\
\text { memasak nasi, air panas } \\
\text { dan lain-lain. }\end{array}$ & $\begin{array}{l}83 \% \text { sangat setuju } \\
17 \% \text { setuju }\end{array}$ \\
\hline
\end{tabular}

Berdasarkan angket menunjukkan sebagian besar dari peserta belum memahami kebermanfaatan serbuk kayu, pengetahuan mereka terbatas ditunjukkan dengan adanya jawaban yang masih keliru. Oleh karenanya, kegiatan ini masih sangat relevan dengan kebutuhan masyarakat desa Batu Bandung, terutama dari segi manfaat serbuk kayu sebagai bahan bakar alternatif pengganti gas elpigi dengan menerapkan kompor Buk Ayu berbasis teknologi kerakyatan. Setelah diakannya kegiatan PKM ini menunjukkan terjadi (a) peningkatan pengetahuan atau pemahaman peserta 
tentang kebermanfaatan limbah serbuk sebesar 89 persen. (b) Peningkatan pengetahuan saat demonstrasi media tentang efisiensi Kompor Buk Ayu dibandingkan dengan Kompor Gas Elpigi sebesar 87 persen. (c) Peningkatan pengetahuan teknik perawatan kompor Buk Ayu sebesar 88 persen. Dan (d) Peningkatan keterampilan masyarakat tentang pembuatan kompor serbuk kayu sebesar 86 persen.

Tabel 2. Rekapitulasi Respon Peserta

\begin{tabular}{|c|c|c|}
\hline $\begin{array}{c}\text { Indikator } \\
\text { Efektivitas }\end{array}$ & Capaian & Persentase \\
\hline \multicolumn{2}{|c|}{ Efisien dalam waktu dan suhu pemakaian } \\
\hline
\end{tabular}

KBA memiliki suhu yang tidak $63,7 \%$ jauh berbeda dari KGE ketika memanaskan air hingga mendidih, begitupun KBA memiliki perbedaan waktu yang tidak terlalu lama, KBA hampir mencapai suhu $100^{\circ} \mathrm{C}$ walaupun mengalami penyusutan massa air.

Penghematan Biaya

\begin{tabular}{l|l} 
KBA lebih irit dalam biaya & $91,5 \%$
\end{tabular}

Kelangkaan Bahan bakar

\begin{tabular}{l|l} 
KBA lebih mudah dijumpai & $100 \%$
\end{tabular}

Kepraktisan

KBA lebih praktis karena $77,7 \%$

kompornya bisa didalam tanah untuk memasak dengan jumlah yang besar di acara persedekahan misalnya memasak nasi, air panas dan KBA bisa ditanam didalam tanah.

\section{Kesimpulan}

Kompor Serbuk Kayu Sangat

Efektif dalam efektivitas suhu

dan waktu pemakaian, lebih

hemat biaya, bahan bakar mudah

dijumpai dan lebih praktis.

Kegiatan pengabdian ini tergolong berhasil rata-rata peningkatan melebihi 70 persen yakni terjadi peningkatan sekitar 87,5 persen. Seluruh peserta menghadiri kegiatan dan mengikuti seluruh materi PKM mulai dari pembukaan, kebermanfaatan serbuk kayu, simulasi pembuatan kompor Buk Ayu, dan mengamati langsung dalam membandingkan efisiensi kompor serbuk kayu dan sekam padi (KOKADI) dengan kompor gas Elpigi (KGE). Rangkaian kegiatan PKM yang dilakukan sebagai upaya meningkatkan keterampilan dan ketertarikan para peserta untuk mencoba melakukan pembuatan kompor serbuk kayu dan sekam padi.

\section{Kesimpulan}

Hasil pelaksanaan rangkaian kegiatan PKM ini menunjukkan bahwa Kegiatan pengabdian ini tergolong berhasil karena terjadi peningkatan pengetahuan Sekitar 87,5 persen yakni terjadi (a) peningkatan pengetahuan atau pemahaman peserta tentang kebermanfaatan limbah serbuk kayu dan sekam padi (KOKADI sebesar 89 persen. (b) Peningkatan pengetahuan saat demonstrasi media tentang efisiensi Kompor serbuk kayu dan sekam padi (KOKADI dibandingkan dengan Kompor Gas Elpigi sebesar 87 persen. (c) Peningkatan pengetahuan teknik perawatan kompor serbuk kayu dan sekam padi (KOKADI sebesar 88 persen. Dan (d) Peningkatan keterampilan masyarakat tentang pembuatan kompor serbuk kayu dan sekam padi (KOKADI sebesar 86 persen. Kegiatan pengabdian ini tergolong berhasil rata-rata peningkatan melebihi 70 persen yakni terjadi peningkatan sekitar 87,5 persen. Seluruh peserta menghadiri kegiatan dan mengikuti seluruh materi PKM mulai dari pembukaan, kebermanfaatan serbuk kayu dan sekam padi (KOKADI, simulasi pembuatan kompor serbuk kayu dan sekam padi (KOKADI, dan mengamati langsung dalam membandingkan efisiensi KOKADI dengan kompor gas Elpigi (KGE).

\section{Ucapan Terima Kasih}

Pengabdian ini didanai dari dana Hibah STKIP PGRI Lubuklinggau Tahun Anggaran 2021.

\section{Daftar Pustaka}

Agustinus, La Ode Musa, 2014. Tungku Hemat Energi Dengan Berbahan Bakar Briket Ampas Sagu. Jurnal Teknik Mesin SINERGI NO. 1, TAHUN 12, APRIL 2014. Politeknik Negeri Ujung Pandang. 88-100.

Asfar, A.M.I.A., Arifuddin, W., \& Rahman, A. 2019. Pengolahan kayu sepang (Caesalpinia sappan. L) di Desa Biru Kecamatan Kahu Kabupaten Bone Sulawesi Selatan. Jurnal Panrita Abdi, 3(2), 97-104. 
Dewi, P.S., \& Widiyawati, I. 2019. Penerapan teknologi budidaya tanaman obat sebagai upaya pemanfaatan lahan pekarangan di Kelurahan Pabuwaran, Purwokerto, Jawa Tengah. Jurnal Panrita Abdi, 3(2), 105 112.

Effendi., A.H., 2008. Kajian Kinerja Kompor Aman Kebakaran dan Hemat Energi (Kompor AHE). Jurnal Permukiman Vol. 3 No. 1 Mei 2008. Pusat Litbang Permukiman. 15-29.

Herlambang, Y. 2015. Peran Kreativitas Generasi Muda Dalam Industri Kreatif Terhadap Kemajuan Bangsa. Jurnal Teknologi Informasi dan Komunikasi (Tematik), 2(1), 61-71.

Indahyani, T. 2010. Sukses Mengembangkan Desain Seni dan Kerajinan Menjahit Aplikasi Berbahan Dasar Limbah Kain (Kain Perca) bagi Industri Rumah Tangga. Humaniora, 1(2), 431-444.

Karno. 2013. Teknologi Pemanfaatan Limbah. IKIP PGRI Madiun Press.

Lando, A.T., Arifin, A.N., Selintung, M., Sari, K., Djamaluddin, I. \& Carongre, M.A. (2019). Sosialisasi dan Pendampingan Sistem Pengelolaan Sampah Menjadi Kompos Skala Sekolah di SD Inpres Kantisang, Tamalanrea. Jurnal Panrita Abdi, 3(2), 113-124.

Pujiati. 2015. Modul Pemanfaatan Limbah Sintetis. IKIP PGRI Madiun Press.

Setyabudhi, A.L., 2017. Perancangan Sistem Kerja Kompor Ekonomis Dengan Bahan Bakar Oli Bekas. Program Studi Teknik Industri, Sekolah Tinggi Teknik Ibnu Sina, Batam, 9-16.

Sokanandi, dkk. 2014. Komponen Kimia Sepuluh Jenis Kayu Kurang Dikenal : Kemungkinan Penggunaan Sebagai Bahan Baku Pembuatan Bioetanol (Chemical Component Of Ten Planted Less Known Wood Species :Possibility As Bioethanol Raw Materials. Jurnal Penelitian Hasil Hutan Vol. 32 No. 3, September 2014, 209-220.
Sumarsono., M. 2009, Perhitungan Efisiensi Termal Tungku Karbonizer Bahan Bakar Bio- Briket Menggunakan Metoda Tidak Langsung. Prosiding Seminar Nasional Daur Bahan Bakar 2009. B2TE-BPPT, Puspiptek, Cisauk, Tangerang, Banten, 33-36

Syafii, 2006. Sifat Kimia dan Dimensi Serat Kayu Mangium (Acacia mangium Willd.) Jurnal Tropical Wood Science \& Technology Vol.4. No. 1, 28-32.

Wijoyo, 2017. Sifat Fisika Papan Semen Partikel Limbah Serbuk Gergaji Kayu Jati (Tectona Grandis). Program Studi Kehutanan Universitas Mataram, 4-9.

Rudiman, M., Hadi, D. M., Hariani, E., Tranado, E., Andrayani, F., \& Raksun, A. 2021. Pelatihan Pembuatan Urea Molases Blok (Umb) Sebagai Suplemen Sapi Pada Peternak Sapi Potong Di Dusun Gading, Desa Montong Betok, Kecamatan Montong Gading Kabupaten Lombok Timur. Jurnal Pengabdian Magister Pendidikan IPA, 4(2)Setyaningrum, A., \& Hartanto, B.W. (2020). Peningkatan Kapasitas Istri Nelayan dalam Pengolahan Hasil Perikanan di Dusun Kuwaru Desa Poncosari Kabupaten Bantul. Jurnal Panrita Abdi, 4(2), 184 194.

Suryolaksono, B. 2015. Studi Deskriptif Tentang Program Disperindag Dalam Pemberdayaan Usaha Kecil Menengah Kerajinan Tangan (Handycraft) Di Kelurahan Wonorejo Kecamatan Tegalsari Kota Surabaya. Jurnal Kebijakan dan Manajemen Publik, 3(1)

USAID. 2015. Pengolahan Limbah Berbasis Masyarakat. Tim ESP USAID.

Vinda, K. 2017. Efektivitas Program Pemberdayaan Masyarakat dalam Kelompok Usaha Bersama (Studi Kasus Pada Pemberian Bantuan Mesin Jahit Kelompok Usaha Bersama Bunga Sejahtera Desa Ngampungan Kecamatan Bareng Kabupaten Jombang). Publika, 5(1). 